\title{
A survey of Trichoptera from the Tributaries of the Doring and mainstream Olifants Rivers, Cedarberg, South Africa with implications for conservation
}

\author{
FERDINAND C. DE MOOR
}

Department of Freshwater Invertebrates, Makana Biodiversity Centre, Albany Museum, and Department of Zoology and Entomology, Rhodes University, Grahamstown 6139, South Africa

E-mail:f.demoor@ru.ac.za

\begin{abstract}
The tributaries of the Olifants River draining the Cedarberg Mountains in the Western Cape are well known for their diverse fauna of endemic freshwater fish. Aquatic ecosystems in the region have also been identified as being particularly important in terms of ecosystem conservation. Recent surveys of aquatic macroinvertebrates have indicated that the region is rich in Trichoptera, with a number of regional endemic species, some of which are not recognizable as known described species. The distribution of certain species appears to be confined to either the arid east-flowing tributaries of the Doring River or else the wetter west-flowing tributaries of the mainstream Olifants River.
\end{abstract}

Key words: Caddisflies, Western Cape, Cape Floral Kingdom, aquatic biodiversity, distribution patterns, endemic fish, endemic invertebrates

\section{Introduction}

The fynbos biome in the Western Cape (Fig. 1), which has been designated by Takhtajan (1986) as the Cape Floral Kingdom (CFK), is recognized for its great diversity of species. More than 9000 vascular plant species have been recorded in the region, of which $68.7 \%$ are endemic (Goldblatt $\&$ Manning 2002). The freshwater fish fauna of the CFK is not very diverse in terms of species numbers, but contains 16 out of the 19 indigenous species endemic to the region (Impson et al. 2002). The tributaries of the Olifants River (within the CFK biome) harbour the highest percentage of endemic fish species in South Africa. The greatest regional species diversity and highest degree of endemism for Trichoptera in South Africa is also found in this region, which was considered a distinct hydrobiological region by Harrison (1959). The Trichoptera of the CFK have been studied in some detail and are considered to be reasonably well known (Barnard 1934, 1940; de Moor 1993, 1997, 1999, 2007; de Moor \& Scott 2003; Harrison \& Elsworth 1958; Harrison \& Agnew 1962; King 1981, 1983; Scott 1955, 1958, 1961, 1983; Scott \& de Moor 1993). Recent surveys have, however, revealed a considerable number of new distribution records including some of undescribed species (de Moor 2007). There is evidence that many of the species occurring in the CFK have temperate Gondwana origins, which suggests that these species are relict survivors of a oncewidespread temperate southern fauna dating back about 140 million years prior to the breakup of Gondwana (Scott \& de Moor 1993). 
The introduction of alien fish - particularly carp (Cyprinus carpio Linnaeus) smallmouth bass (Micropterus dolomieu Lacepede) and largemouth bass (M. salmoides (Lacepede)) - have decimated the largely endemic fish fauna in the Olifants River system (de Moor \& Bruton 1988). Conservation efforts, within aquatic ecosystems, have therefore focused on preserving the last remaining populations of these fish (Impson et al. 2002, Lowe et al. 2008).

Recent initiatives have, however, emphasized the development of a more holistic approach to conservation assessments and planning (Margules \& Pressey 2000). While the status of fish remains a primary concern, it has now been realized that species assemblages of aquatic invertebrates in different rivers within the CFK can provide an extremely useful tool in developing 'river signatures' to describe the unique attributes of individual river systems (Nel et al. 2006; de Moor 2007, Roux et al. 2002; 2008). Since the Trichoptera have been found to have a high diversity, and possibly a high degree of endemism, in these river systems, a renewed emphasis on investigating the distribution patterns and species assemblages of this taxon in rivers of the CFK region has been initiated.

The broad general aims of such an initiative would be to focus on the following three aspects:

1. To compare macroinvertebrate species composition in the east- and west-flowing rivers within the Cedarberg region;

2. To compare the species composition of macroinvertebrates in the Cedarberg region with that of other rivers within the $\mathrm{CFK}$; and

3. To investigate the usefulness of including selected macroinvertebrate taxa as indicator species in the development of 'river signature' assessments, used for the purpose of conservation planning.

In recent surveys of rivers in the region, only the aquatic stages of insects were collected, which was not adequate for identification to species level (Lowe et al. 2008). In order to fulfill the aims outlined in points (1) and (2) above, it was necessary to collect adult insects to confirm species identification.

The current study represents a preliminary investigation into selected rivers in the Cedarberg, the aim being to assess some of the distribution patterns of selected macroinvertebrate species. A single 10-day survey of 11 selected rivers was undertaken during which assessments were confined to the morphotaxonomic status of the species collected. Most macroinvertebrate taxa encountered were collected but this paper deals only with Trichoptera.

The rare fish fauna on which previous studies have focused has been thoroughly surveyed and the distribution patterns of the species are well known. The macroinvertebrate survey undertaken has covered some of the rivers where the rare fish were still recorded. One of the aims of the study was to assess the species of macroinvertebrates usually associated with fish occurring at particular sites, or which species were to be found upstream of barriers to the indigenous fish. If unique associations between fish and macroinvertebrates can be shown to occur, this would present additional information to influence conservation decisions. In such cases the emphasis would shift from a narrow focus on fish conservation, to a broader approach of conserving the conditions for maintaining assemblages of all species, including macroinvertebrates, within unique river systems.

\section{Study area and methods}

During a 10-day collecting excursion, 12-22 April 2005, 12 sites on 9 rivers in the Cedarberg Mountains were extensively sampled (Fig. 1). At each sampling station physicochemical data were recorded, $\mathrm{pH}$ was measured using a Eutech Instruments Cyberscan pH 300 meter and electrical conductivity $\mu \mathrm{Scm}^{-1}$ (EC) and total dissolved solids $\mathrm{mg} l^{-1}$ (TDS) were recorded with a WTW LF 95 conductivity meter. Temperature at the time of sampling was recorded with both meters. Digital 


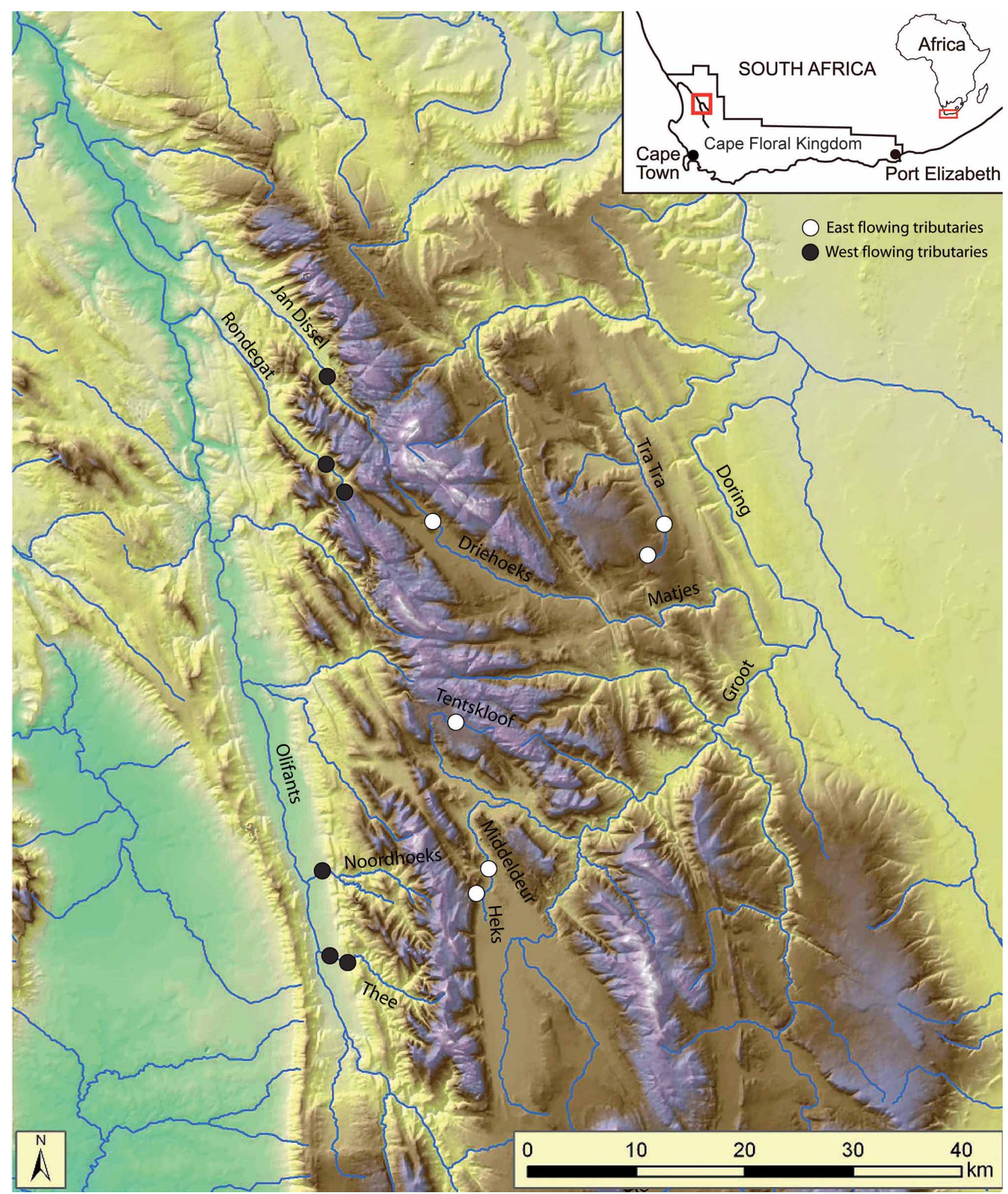

FIGURE 1. Map showing location of the rivers and sampling sites in the Cedarberg and location of the CFK in South Africa.

pictures were taken of the general aquatic environment giving a visual record of the aquatic biotopes and prevailing conditions at the time of sampling. Aquatic invertebrates were sampled using a selection of various water and aerial hand nets ranging in net mesh size from $80 \mu \mathrm{m}(0.08 \mathrm{~mm})$ to $1000 \mu \mathrm{m}(1 \mathrm{~mm})$. Sampling of aquatic stages was done using a standard SASS net (mesh size $1 \mathrm{~mm}$ ) 
(Dickens \& Graham 2003); a hand-net (mesh size $250 \mu \mathrm{m}$ ); a small D hand-net (mesh size $80 \mu \mathrm{m}$ ) for sampling bedrock in swift flowing cascades and hygropetric splash zones of waterfalls. General hand-picking of stones, lodged branches and removable substrates was also accomplished. A wide diversity of aquatic biotopes was sampled at each site. Light traps using a super-actinic light source over a white tray to collect the adult stages of many aquatic insects were set at all sites and where conditions were suitable. Emergence traps were set for several days at many sites. Malaise traps next to streams were also set where feasible. Drift nets were set in the water at dusk to collect the nymphal and larval shucks of emerging insects. Where time permitted, general collecting of flying adult insects using hand nets was also carried out. Samples collected were given a catalogue number for each site, date and biotope and were preserved in $80 \%$ ethanol. Material was recorded under the Cedarberg Rivers catalogue (CED) in the Albany Museum collection for ease of retrieval and regional recognition of the collection.

For statistical analysis, Trichoptera distribution data from sites on some rivers were combined to make a between-rivers assessment of community distribution patterns possible. For a study on the ordination of the data, non-metric multidimensional scaling (MDS) was used in preference to principal components analysis (PCA) because of the highly heterogeneous nature of the community data and also because MDS makes fewer assumptions about the interrelationship of the samples or form of the data than PCA. The statistical package PRIMER version 6 (Clarke \& Gorley 2006) was used to conduct the MDS test and run an ANOSIM to test if there was a significant difference between identified communities.

Although aquatic invertebrates from many taxa were collected, this paper will report on only the Trichoptera found during this survey.

\section{Results and discussion}

The $\mathrm{pH}$ of all the rivers surveyed was acid, ranging from 5.4 to 6.3; all waters had low levels of TDS ranging from 15 to $57 \mathrm{mg} \mathrm{\ell}^{-1}$, and electrical conductivity ranging from 4 to $66 \mu \mathrm{S} \mathrm{cm}^{-1}$. Water temperature at the time of sampling ranged from $9.4-19.8^{\circ} \mathrm{C}$.

A total of 44 taxa of caddisflies in 10 families were recorded from the survey undertaken (Table 1). Twenty of these taxa represent known and described species. Of the 25 remaining taxa that were recorded, 13 were collected only as larvae and could thus belong to presently-known and described adults of species for which the correlation with larvae is not known, or they could represent larvae of undescribed species. The remaining 12 species could not be placed into known described species and may represent undescribed species or morphological variants of known species. These will be discussed in some detail below. The streams draining west directly into the Olifants River contributed 31 taxa and those draining east into the Doring River contributed 29 taxa of Trichoptera. The Thee and Noordhoeks rivers produced the greatest diversity of Trichoptera species in the west draining rivers and the Hex-Middeldeur River the most in the east draining rivers.

The family Philopotamidae is represented by 2 genera and 6 known species in the CFK. In the present survey it was represented by Chimarra ambulans Barnard in the Noordhoeks and Jan Dissels rivers, the larvae of a Thylakion species in the Thee River and larvae of Chimarra species from the Jan Dissels, Tentskloof, Tra Tra and Dassiekloof rivers.

The family Hydropsychidae is represented by 4 genera and 8 known species in the CFK. The widespread species Cheumatopsyche afra s.l.(Mosely) was recorded only from the Thee and Noordhoeks rivers and Cheumatopsyche maculata (Mosely) - a species known to occur in the upper erosional reaches of streams (Scott et al. 1988)—was expectedly recorded in the Rondegat, Upper 
Hex (Middeldeur) and Tentskloof rivers. Macrostemum capense (Walker) was recorded from the Jan Dissels and Driehoek rivers. Undescribed larvae of a Cheumatopsyche species were recorded in all the westward-flowing tributaries of the Olifants River and from the Driehoeks and Tra Tra rivers.

TABLE 1. Species and numbers of Trichoptera recorded at each of the rivers during the survey undertaken in 2005.

\begin{tabular}{|c|c|c|c|c|c|c|c|c|c|}
\hline TRICHOPTERA & $\stackrel{\Xi}{E}$ & 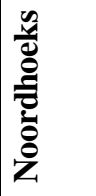 & 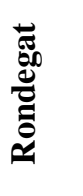 & 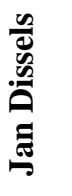 & 坖 & 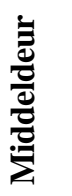 & 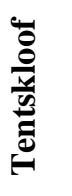 & مَ & $\underset{E}{\mathbb{E}}$ \\
\hline \multicolumn{10}{|l|}{ Philopotamidae } \\
\hline Chimarra ambulans Barnard 1934 & - & 2 & - & 1 & - & - & - & - & - \\
\hline Chimarra spp. Larvae & - & - & - & 4 & - & - & 13 & 2 & 17 \\
\hline Thylakion sp. Larvae & 1 & - & - & - & - & - & - & - & - \\
\hline \multicolumn{10}{|l|}{ Hydropsychidae } \\
\hline Cheumatopsyche afra (Moseley) 1935 & 21 & 71 & - & - & - & - & - & - & - \\
\hline Cheumatopsyche maculata (Moseley) 1934 & - & - & 9 & - & 4 & - & 8 & - & - \\
\hline Cheumatopsyche sp. CED42AA & 80 & 108 & 16 & 48 & - & - & - & 2 & 4 \\
\hline Genus Polymorphanisini CED31D & 1 & 39 & - & - & - & - & - & - & - \\
\hline Macrostemum capense (Walker) 1852 & - & - & - & 1 & - & - & - & 14 & - \\
\hline \multicolumn{10}{|l|}{ Dipseudopsidae } \\
\hline Dipseudopsis sp. & - & - & - & - & - & - & - & - & 1 \\
\hline \multicolumn{10}{|l|}{ Ecnomidae } \\
\hline Parecnomina resima Morse 1974 & - & - & 2 & - & 4 & - & - & 3 & - \\
\hline Ecnomus kimminsi Scott 1963 & - & 3 & - & - & - & - & - & - & - \\
\hline Ecnomus similis Moseley 1932 & - & 4 & - & - & - & - & - & - & - \\
\hline Ecnomus sp. CED31P & 1 & - & - & - & - & - & - & - & - \\
\hline Ecnomus sp. CED31Q & 1 & - & - & - & - & - & - & - & \\
\hline Ecnomus spp. & - & 11 & 4 & 6 & - & - & - & - & - \\
\hline \multicolumn{10}{|l|}{ Polycentropodidae } \\
\hline Paranyctiophylax sp. & - & - & - & 1 & - & - & - & - & - \\
\hline \multicolumn{10}{|l|}{ Hydroptilidae } \\
\hline Hydroptila cruciata Ulmer 1912 & 28 & 28 & - & 2 & - & 9 & - & - & - \\
\hline Hydroptila sp CED30G & 12 & - & - & - & - & - & - & - & - \\
\hline Ortthotrichia barnardi Scott 1963 & - & 3 & - & 2 & - & - & - & - & - \\
\hline Orthotrichia sp. & 1 & - & - & - & 1 & - & - & - & - \\
\hline Oxyethira velocipes (Barnard) 1934 & 30 & - & - & - & 2 & 13 & 1 & - & - \\
\hline Oxyethira sp. & - & - & - & - & 4 & - & - & 1 & - \\
\hline \multicolumn{10}{|l|}{ Leptoceridae } \\
\hline Athripsodes harrisoni (Barnard) 1934 & 28 & 64 & - & - & - & 1 & - & - & - \\
\hline Athripsodes prionii Scott 1958 & - & - & - & - & - & - & - & - & 8 \\
\hline Athripsodes schoenobates (Barnard) 1934 & - & - & - & - & - & 4 & - & - & - \\
\hline Athripsodes sp. CED4X larvae & - & - & 2 & - & 8 & - & 4 & - & 2 \\
\hline Athripsodes sp. SCR164P & 3 & - & - & - & - & - & - & - & - \\
\hline Athripsodes spp. & - & - & - & - & 1 & - & - & 100 & - \\
\hline
\end{tabular}

...... continued next page 
TABLE 1 (continued)

\begin{tabular}{|c|c|c|c|c|c|c|c|c|c|}
\hline TRICHOPTERA & $\stackrel{\Xi}{E}$ & 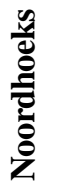 & 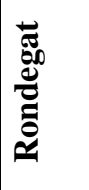 & 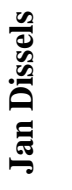 & 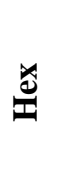 & $\begin{array}{l}\frac{\Xi}{0} \\
\frac{0}{0} \\
\frac{0}{0} \\
\frac{0}{2} \\
\Sigma\end{array}$ & 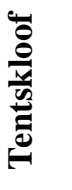 & 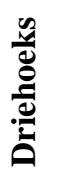 & 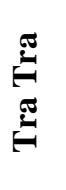 \\
\hline Athripsodes bergensis Scott 1958 & 1 & 20 & 4 & & & & 60 & 1 & 2 \\
\hline Leptecho helicotheca Scott 1958 & 1 & 1 & 3 & 1 & - & - & - & - & - \\
\hline Leptecho lupi (Barnard) 1934 & - & - & - & - & 3 & - & - & - & - \\
\hline Leptecho sp. CED12B adult & - & - & - & - & - & 1 & 1 & - & - \\
\hline Leptecho sp. CED13E adult & - & - & - & - & 1 & 5 & 3 & - & - \\
\hline Leptecho sp. CED13G adult & - & - & - & - & 1 & 9 & - & - & - \\
\hline Leptecho sp. CED4Y larvae & - & - & - & - & 69 & - & - & - & - \\
\hline Leptecho spp. & 6 & - & - & 9 & 2 & - & 36 & 1 & - \\
\hline Oecetis modesta (Barnard) 1934 & - & - & 4 & - & - & - & - & - & 2 \\
\hline Oecetis sp. & 6 & 1 & 1 & 25 & 25 & - & 2 & 6 & - \\
\hline \multicolumn{10}{|l|}{ Sericostomatidae } \\
\hline Petroplax caricis Barnard 1934 & - & - & - & - & - & - & 1 & - & - \\
\hline Petroplax curvicosta Scott 1955 & 5 & 4 & - & - & - & - & - & - & 5 \\
\hline Petroplax sp. & - & - & - & 4 & - & - & - & - & - \\
\hline ?Cheimacheramus sp. Larvae & - & - & $21 *$ & - & - & - & - & - & - \\
\hline \multicolumn{10}{|l|}{ Barbarochthonidae } \\
\hline Barbarochthon sp. & - & - & - & - & 3 & - & 31 & 1 & 2 \\
\hline \multicolumn{10}{|l|}{ Petrothrincidae } \\
\hline Petrothrincus circularis Barnard 1934 & - & - & 4 & 2 & 26 & - & 2 & - & 6 \\
\hline TOTAL species & 17 & 14 & 10 & 13 & 15 & 7 & 13 & 10 & 10 \\
\hline
\end{tabular}

By far the most interesting find was the collection of females of an undescribed genus and species belonging in the tribe Polymorphanisini from the Noordhoeks and Thee rivers. This record considerably extends the distributional range of the tribe, known previously only from the eastern sub-tropical regions of South Africa in KwaZulu-Natal and along the western border of the Limpopo River. What is needed, however, are some males of this species to enable a proper description and selection of a type specimen to represent the species and genus.

The larva of a species of Dipseudopsis was collected from the Tra Tra River. The Dipseudopsidae were under-collected during the survey and were expected to be more common. Because of the unusual burrowing behaviour of the larvae, it would be necessary to adopt special collecting techniques to reflect a reliable representation of this genus in the study area.

Eight species of Ecnomus and 1 species of Parecnomina are known from the western Cape. In the present survey Ecnomus kimminsi Scott and E. similis Mosely were recorded from the Noordhoeks River and Parecnomina resima Morse from the Rondegat, Hex (Middeldeur) and Driehoeks rivers. Two undescribed species of Ecnomus were recorded from the Thee River.

Polycentropodidae have not been previously recorded from the western Cape and larvae of a species of Paranyctiophylax that were collected from the Jan Dissels River will most likely represent an undescribed species.

Although 10 possible species of Hydroptilidae have been previously recorded from the western Cape, the micro-caddisfly family Hydroptilidae has not been adequately studied in South Africa. 
Three known species were recorded during this survey. Hydroptila cruciata Ulmer was recorded from both east- and west-flowing tributaries of the Olifants and Doring rivers. Orthotrichia barnardi Scott was found only in the swift flowing cobble-beds of the Noordhoeks and Jan Dissels rivers. Oxyethira velocipes (Barnard) was the most widespread species, being found in the Thee, Hex, Middeldeur and Tentskloof rivers. An undescribed species of Hydroptila was found in the Thee River.

Of all the Trichoptera families recorded from South Africa, the Leptoceridae-with more than 50 species in 10 genera-attains its greatest diversity in the CFK. At least 14 species were recorded in the present survey and 6 of these are undescribed species. One undescribed species of Athripsodes was found only in the Thee River and a second of the same genus was recorded in the Rondegat, Hex, Driehoeks and Tra Tra rivers. Three undescribed species of Leptecho were recorded in the Middeldeur River and 2 more species from the same genus were also found in the Tentskloof River. The remarkable Leptecho helicotheca Scott, a leptocerid larva that constructs a helical snail-shellshaped case of sand grains, was recorded from all the west-flowing tributaries of the Olifants River but was not found in any of the tributaries of the Doring River.

Four genera and 12 species from the family Sericostomatidae have previously been recorded from the CFK. In the present study records of Petroplax caricis Barnard were obtained from the Tentskloof River, and P. curvicosta Scott were recorded in the Thee, Noordhoeks and Tra Tra rivers. Unidentified specimens of what may prove to be the undescribed larvae of Cheimacheramus caudalis Barnard, were collected from a small seeping tributary of the Rondegat River.

Larvae of Barbarochthon, that would represent either a morphological variation of the species $B$. brunneum Barnard or an undescribed species in this genus, were collected from the Hex, Tentskloof, Driehoeks and Tra Tra rivers, notably only in the east-flowing tributaries of the Doring River. The variation observed in these larvae casts some doubt on its restricted monospecific species status.

Empty pupal cases and some pupae - presumably Petrothrincus circularis Barnard-were collected from the Rondegat, Jan Dissels, Hex, Tentskloof and Tra Tra rivers. If positively identified, this would represent a considerable range extension for this genus. The species identification will have to be confirmed from adults that need to be collected or reared from larvae or pupae.

The MDS ordination of similarities of taxa (based on presence/absence data) calculated for all combinations of sites from the 9 selected rivers, revealed a reliable 2-dimensional separation (stress value $=0.08$ ) of east and west flowing rivers (Fig. 2). Global analysis of similarity between the east and west flowing rivers ANOSIM produced an $\mathrm{R}=0.44(\mathrm{p}=0.024)$ indicating that the fauna of the east and west flowing rivers differed significantly.

\section{Conclusions}

A single 10-day survey of 11 selected tributary rivers of the Olifants River and its main eastern tributary, the Doring River, in the Cedarberg mountains has revealed that there are still several undescribed species. The distribution patterns of Trichoptera species also show that there is an apparent difference in species composition between the east- and west-flowing rivers. Leptecho helicotheca was only recorded in the west-flowing tributaries and Barbarochthon brunneum was only recorded in the east-flowing tributaries. The highest Trichoptera species diversity was recorded in the Thee River (17) and Noordhoeks River (14) in the west and in the Hex River (15) in the east (Table 1). This species diversity appears low when compared to that of the Salt River in the southern Cape where 29 species were recorded over a 4-year period during which 3 surveys were undertaken (de Moor 2007). This emphasizes the importance of seasonal and annual variations in species 
composition recorded in rivers. The single survey undertaken in the present study represents a "snap shot" estimation of Trichoptera species distribution and diversity.

In addition to the present work on identification and distribution of species in the CFK region, a molecular-systematic assessment of the frequently-found disjunct populations of many of these Gondwana species also needs to be conducted. Colleagues in the USA, Great Britain and Switzerland as well as students at Rhodes University have commenced studies on this aspect, and results could further enhance our understanding of the biodiversity and distribution patterns of the Trichoptera in the CFK region.

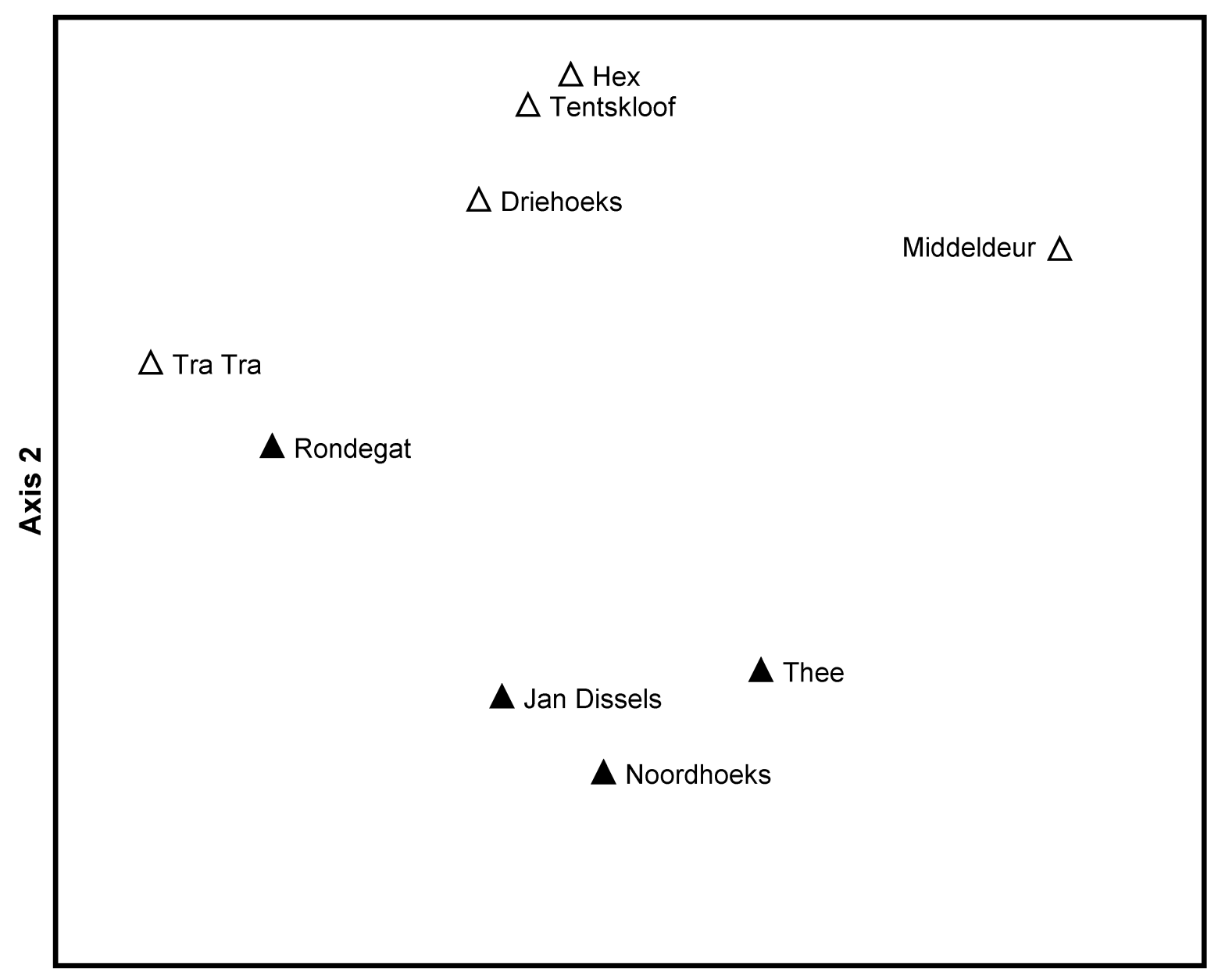

\section{Axis 1}

FIGURE 2. Multidimensional ordination of 9 river sites based on absence/presence of taxa. Stress $=0.08$ indicates a reliable 2-dimensional separation of the data.

\section{Acknowledgements}

Roger Bills, South African Institute for Aquatic Biodiversity (SAIAB), is thanked for organizing the field excursion and assisting with collecting. Comments and suggestions made by reviewers improved the paper. Constructive advice on the statistical analysis of data by Peter Wiberg-Larsen improved the interpretation of the results. Irene de Moor is thanked for assistance in the field and for passing editorial comments on the manuscript. Mbongeni Baninzi is thanked for helping sort, clean 
and pre-identify samples collected. Sylvia de Moor added details to the map provided by Roger Bills. The Water Research Commission (WRC) and National Research Foundation (NRF) provided funding for the research. The Directorate of Museums and Heritage, Eastern Cape, are thanked for providing research facilities and encouraging this research.

\section{References}

Barnard, K.H. (1934) South African caddis-flies (Trichoptera). Transactions of the Royal Society of South Africa, 21, 291-394.

Barnard, K.H. (1940) Additional records, and descriptions of new species, of South African Alder-flies (Megaloptera), May-flies (Ephemeroptera), Caddis-flies (Trichoptera), Stone-flies (Perlaria), and Dragon-flies (Odonata). Annals of the South African Museum, 32 (6), 609-661.

Clarke, K.R. \& Gorley, R.N. (2006) PRIMER v6: User Manual/Tutorial, PRIMER-E, Plymouth, UK, 190 pp.

de Moor, F.C. (1993) Factors influencing the distribution of Trichoptera in South Africa. pp. 51-58. In: Otto, C. (Ed.), Proceedings of the 7th International Symposium on Trichoptera. Backhuys Publishers, Leiden, 312 pp.

de Moor, F.C. (1997) An unusual caddisfly larva from South Africa, a possible member of the Triplectidinae (Trichoptera: Leptoceridae). In: Holzenthal, R.W. \& Flint, O. S. (Eds), Proceedings of the 8th International Symposium on Trichoptera. Ohio Biological Survey, pp. 323-330.

de Moor, F.C. (1999) The use of Trichoptera to assess biodiversity and conservation status of South African river systems. In: Malicky, H. \& Chantaramongkol, P. (Eds), Proceedings of the 9th International Symposium on Trichoptera, Chiang Mai, pp. 237-244.

de Moor, F.C. (2007) Regional biogeographical differences in Trichoptera diversity in South Africa: Observed patterns and processes. In: Bueno-Soria, J., Barba-Alvares, R. \& Armitage, B. (Eds). Proceedings of the $12^{\text {th }}$ International Symposium on Trichoptera, Mexico City. The Caddis Press, pp. 211-218.

de Moor, F.C. \& Scott, K.M.F. (2003) Trichoptera. Chapter 5. In: de Moor, I.J., Day, J.H. \& de Moor, F.C. (Eds), Guides to the Freshwater Invertebrates of southern Africa. Volume 8: Insecta II: Hemiptera, Megaloptera, Neuroptera, Trichoptera \& Lepidoptera. Water Research Commission Report No. TT214/03, Gezina, South Africa, pp. 84-181.

de Moor, I.J. \& Bruton, M.N. (1988) Atlas of alien and translocated indigenous aquatic animals of southern Africa. South African National Scientific Programmes Report No. 144, 310 pp.

Dickens, C.W.S. \& Graham, M.P. (2002) The South African Scoring System (SASS) version 5 Rapid Bioassessment Method for Rivers. African Journal of Aquatic Science, 27, 1-10.

Goldblatt, P. \& Manning, J.C. (2002) Plant diversity of the Cape region of southern Africa. Annals of the Missouri Botanical Garden, 69 (2): 261-302.

Harrison, A.D. (1959) General statement on South African Hydrobiological Regions. Report No. 1. Project 6.8H. Internal Report, National Institute for Water Research, CSIR, Pretoria, South Africa, 12 pp.

Harrison, A.D. \& Agnew, J.D. (1962) The distribution of invertebrates endemic to acid streams in the western and southern Cape Province. Annals of the Cape Provincial Museums (Natural History), 2, 273-291.

Harrison, A.D. \& Elsworth, J.F. (1958) Hydrobiological studies on the Great Berg River, Western Cape Province. Part 1. General description, chemical studies and main features of the flora and fauna. Transactions of the Royal Society of South Africa, 35 (3), 125-226.

Impson, N.D., Bills, I.R. \& Cambray, J.A. (2002) A conservation plan for the unique and highly threatened freshwater fishes of the Cape Floral Kingdom, Chapter 39. In: Collares-Pereira, M.J., Coelho, M.M. \& Cowx, I.G. (Eds). Conservation of Freshwater Fishes: Options for the Future, Blackwell Science. pp. 432-440.

King, J.M. (1981) The distribution of invertebrate communities in a small South African river. Hydrobiologia, 83, $43-65$.

King, J.M. (1983) Abundance, biomass and diversity of benthic macro-invertebrates in a western Cape river, South 
Africa. Transactions of the Royal Society of South Africa, 45 (1), 11-34.

Lowe, S.R., Woodford, D.J. Impson, N.D. \& Day, J.A. (2008) The impact of invasive alien fish and invasive riparian plants on the invertebrate fauna of the Rondegat River, Cape Floristic Region, South Africa. African Journal of Aquatic Science, 33 (1), 51-62.

Margules, C.R. \& Pressey, R.L. (2000) Systematic conservation planning. Nature, 405, 243-253.

Nel, J.L., Smith-Adao, L., Roux, D.J., de Moor, F.C., Cambray, J.A., Adams, J., Maree, G., Kotze, I., Smith, R.J., Kleynhans, C.J., Moolman, J. \& Thirion, C. (2006) Conservation planning for river and estuarine biodiversity in the Fish to Tsitsikamma Water Management Area. Water Research Commission Report K5/1486. Water Research Commission, Pretoria, South Africa. 106 pp.

Roux, D.J., de Moor, F.C., Cambray, J.A. \& Barber-James, H.M. (2002) Use of landscape-level river signatures in conservation planning: A South African case study. Conservation Ecology, 6 (2), 6. Available from http:// www.consecol.org/vol6/iss $2 /$ art6

Roux D.J., Nel, J.L., Ashton P.J., Deacon A.R., de Moor F.C., Hardwick D., Hill L., Kleynhans N., Maree G.A., Moolman J. \& Scholes R.J. (2008) Designing protected areas to conserve riverine biodiversity: Lessons from a hypothetical redesign of the Kruger National Park. Biological Conservation, 141, 100-117.

Scott, K.M.F. (1955) Some new caddisflies (Trichoptera) from the Western Cape Province, 1. Annals of the South African Museum, 41 (6), 367-380.

Scott, K.M.F. (1958) Some new caddisflies (Trichoptera) from the Western Cape Province, 2. Annals of the South African Museum, 44 (2), 39-52.

Scott, K.M.F. (1961) Some new caddisflies (Trichoptera) from the Western Cape Province, 3. Annals of the South African Museum, 46 (2), 15-33.

Scott, K.M.F. (1983) On the Hydropsychidae (Trichoptera) of Southern Africa with keys to African genera of imagos, larvae and pupae and species lists. Annals of the Cape Provincial Museums (Natural History), 14 (8), $299-422$.

Scott, K.M.F., de Moor, F.C. \& Kohly, N. (1988) Life History Alternatives in the genus Cheumatopsyche (Trichoptera: Hydropsychidae) in southern Africa. Trichoptera Newsletter (Lunz, Austria), 15, 15-16.

Scott, K.M.F. \& de Moor F.C. (1993) Three recently erected Trichoptera Families from South Africa, the Hydrosalpingidae, Petrothrincidae and Barbarochthonidae (Integripalpia: Sericostomatoidea) with a cladistic analysis of the character states in the twelve families here considered as belonging to the Sericostomatoidea. Annals of the Cape Provincial Museums (Natural History),18 (14), 293-354.

Takhtajan, A. (1986) Floristic regions of the world. University of California Press, Berkley, California, 522 pp. 